\title{
EXPRESSION OF DIALOGUE BETWEEN CHILD AND ADULT IN PRE-SCHOOL: THEORETICAL ASPECT
}

\author{
Inesa Vietienè \\ Šiauliai University, Lithuania
}

\begin{abstract}
As economic, social and political conditions are rapidly changing and information and communication technologies are constantly developing, the approach towards the child and his education in childhood is changing in a modern society too. Child education is based on the mutual dialogue between child and adult which is often interpreted in the context of communication theory by addressing the question on the ways and forms of conveying information as well as by searching for the possibilities of correct and effective communication. A deeper understanding of dialogue expression is supplemented and enriched by the hermeneutic approach by the author which enables one to interpret the diversity of child and adult as well as learner and educator experiences. Hermeneutics provides conditions for child education to be perceived in a formal environment, i.e. pre-school, as a multi-dimensional and unique process. From the hermeneutic perspective, the dialogue between child and adult is oriented towards the problem of understanding where the understanding of the whole by interpreting personal experience and its perception rather than participation and interaction is of particular importance.
\end{abstract}

Keywords: dialogue between child and adult, pre-school, hermeneutics.

\section{Introduction}

Current globalisation processes and rapid change of all spheres of life related to them, the growing knowledge-based society needs and requirements for the education system are changing the attitude towards a child and his education in childhood. The period of childhood is gaining a special significance in today's society as children are the youngest and most socially dependant social group.

According to O. Monkevičienè (2009), the education of a contemporary child is perceived as dependant on the socio-cultural field of communication: child and family, child and teacher, family and educational institution, educational institution and community, i.e. social and cultural environment of a child. Thus, the quality of education in pre-school is guaranteed by a full-pledged intercultural dialogue of a child and an adult and by the expression of this dialogue in a formal education environment. This process is studied and analysed in various aspects by many foreign scholars (Sotirou, 2012, 1993; Schröer, 2009; Freire, 2009; Tanaka, 2005; Gillert, 2003; Yoshida \& Matsumoto, 2002; Schachinger, 2000; Sterfeldt \& 
Mathiasen, 1999; McLaughlin, 1997) and by Lithuanian scientists and practitioners (Garšvè, 2014, 2012, 2011; Čičelis, 2013; Lukočiūtè, Mickutė, \& Mažeikis, 2009; Mažeikis \& Lenkauskaitė, 2008; Martišauskienė, 2008; Duoblienè, 2006; Kontautienè, 2006; Juodaitytè, 2007, 2004, 2003, 2002; Bitinas, 2004; Jakavičius, 1998 and others).

According to A. Juodaityte (2004), child-centered education liberates the child from addiction of adults and creates favourable conditions for the formation of competencies and development based on experience in acceptable ways. The scientist states that priorities are given to children's experimentations and testing as with such means children's relationship with the real world is strengthened. For children it is especially important to learn how to live and get along with different people and how to appropriately socialize in the surrounding environment.

The research problem. Compared to previous children generations, generation $\mathrm{Z}$ or digital technology children have special skills as they grow up with computers, interactive whiteboards, mobile phones, cameras, digital books and toys. They are confident and optimistic, willing to look for information, see and hear for themselves. They like to explore and solve problems. They quickly get interested in something and can be involved in several activities at the same time. They also may do something for a long time if the activity has game elements.

Taking into account abilities and needs of modern children, today's education is based on child-oriented paradigm which requires an aggregate approach to child's personality, his skills and aspirations to act freely and without restrictions. According to A. Juodaityte (2002), in child-centered educational environment a child is expressing himself as a "part of nature" and a "creator of culture". A child as a "part of nature" frees his natural and innate abilities (activity, mobility, curiosity) and a child as a "creator of culture" adapts to the environment by perceiving and actualizing experience.

Thus, the rapid change of social life and its postmodernism in today's global society determine that education of children is based on a mutual intercultural dialogue between a child and an adult. Considering this, research object is the expression of a dialogue between a child and an adult in pre-school.

Research aim is to reveal the expression of a dialogue between a child and an adult in pre-school.

Research tasks are to present the meaning of dialogue, reveal possibilities of a dialogue expression between a child and an adult in pre-school based on the analysis of scientific literature and hermeneutics.

Research methods are analysis of scientific literature and meta-analysis. 


\section{The definition of dialogue}

Dialogue is a conversation of two or more people (Jovaiša, 2003). L. Duoblienè (2006) considers that dialogue, in the strict sense, includes only two people in conversation and, in the broad sense, it includes a conversation of a group or even whole humanity.

Dialogue is a phenomenon that allows a person to interpret the world by instinctively "looking" for someone to communicate: to share experience or simply to convey accumulated emotions or feelings and to express opinion. Dialogue is held not only in words, but also by body language, facial expressions, movements and forms (Čičelis, 2013).

According to M. Gutauskas (2010), dialogue is the essential part of human existence which is of particular importance. This concept is found in politics, education, work, meetings, conferences and everyday life. Dialogue is understood as a connective unit which allows people to understand each other and agree to work together. As a process dialogue is a conversation between me and another person. Dialogue is also a situation of meeting, bodily interaction and staying one before another when spoken about something. Mutual meanings, understanding and consensus appear in conversation. During conversation partners are speaking, turning to each other, understanding and agreeing on something. Thus, for these aspects dialogue is communication, mutual understanding and consensus.

J. Rau (2005) states that dialogue is a way of communication that creates conditions for general perception and provides human relationship with meaning. The author emphasizes the process of dialogue when participating partners are of high opinion of each other. It starts when consciousness inhibit an equal sense of self-esteem and self-respect. Dialogue never happens between a "strong" person and a "weak" person as the "strong" person is trying to ignore the "weaker" or impose his worldview. During dialogue each person has to know who he is, on whose behalf he is speaking, what is his history and how others perceive him. This process cannot occur without tolerance which allows people of different ethical, cultural and political backgrounds not only be together, but also find mutual understanding.

Dialogue as a process of interaction and communication does not have to create a community of the world but has to reveal it. Dialogue always happens in a global context and makes it possible to find the right way by eliminating a subjective personal approach (Wojtyla, 1997). This view is shared by M. Gutauskas (2010). According to him, dialogue often interrupts regular life but never "removes itself" from world events. Relationship which stands the furthest from the essence of dialogue works in the dialogue. Space background of dialogue is communication which is anonymous, standardized and defined in social roles. In each conversation these aspects manifest in dialogue order, politeness, tact, 
compliance with conversation boundaries, avoidance of certain topics, i.e. certain cultural norms and traditions are followed.

According to A. Kazlauskiene (2012), the interaction of dialogue is twosided: information is transmitted and feedback information which has real changes is accepted. A. Mickūnas (2014) provides with another dialogue conception. According to him, dialogue is conducted in three directions: relationship with the subject, relationship with another person and oneself, and that is why it is sometimes defined as trinomial. During this dialogue two people have to take over each other's intentions which reveal the subject, topic, item or content. The same intention means that attitudes of both people coincide. In accordance with the conception of trinomial dialogue it is recognized that relationship of me and another person is a necessary condition for human relationship when one addresses another as a subject and not an object. One entity opens up to another equal entity that possesses direct experience. Trinomial dialogue consists of individuals who do not only stand in front of each other, but also speak about something or consider some kind of activity. Entities understand their positions, their similarities and differences related to some kind of an act or world requirements which shape their relationship. Trinomial dialogue, according to the author, is a form of communication, mutual understanding and certain consensus since the process of dialogue includes not only the speakers, their relationship, emotions and feelings, but also the content of conversation and language which marks objects, subjects and events. Dialogue participants create mutual understanding, feeling and protection of another. The structure of dialogue reveals itself as trinomial when I and another person are seeking for a common objective which is the third key object of dialogue.

G. Mažeikis and J. Lenkauskaite (2008) note that dialogue has its own logic of development, goes beyond the limits of personal attitudes and extends horizons of understanding and explaining. A dialogue itself without the recognition of its evolution and conclusions is not a sufficient action of understanding which comes true by acknowledging it. P. Sotirou (1993) states that the most important feature of dialogue is its interpretation which is clarified by not one but at least two people. The author observes that understanding only occurs in partnership and during dialogue.

In summary, it can be said that very often dialogue is discussed in the context of communication theory by raising the question about the ways and forms of conveying information and by searching correct and affective communication possibilities. Still dialogue is one of the most versatile and interesting experiences in which not as much participation and interaction is important, as the understanding of whole by interpreting one's experience and perception. 


\section{Expression of intercultural dialogue in formal education environment - pre-school}

Living in the present conditions of constant change and adapting to the postmodern life, it is getting interesting to see how the approach towards children being fully-pledged members of community change. According to V. Rubavičius (2003), in a post-modern society a person becomes Prometheus-like and unconstrained. However, this is not always applied to children as they remain „on the fringes of modernism not fulfilling rational and independent ideal of a person" (Corker \& Shakespeare, 2002, p. 3).

Thus, the concept of childhood requires a „new postmodern knowledge and understanding“" (Gellner, 1993, p. 93). The perception of childhood has an actual (at present) and long term (at past, present, future) state which's interpretation belong to hermeneutics (Juodaityte \& Savickis, 2013). Authors believe that the perception of childhood requires openness to the entire diversity of social reality phenomena, to levels of objectivity and subjectivity involving values, goals and meanings. Childhood is a phenomenon of new and postmodern culture and it does not admire a person but respects his dignity which inherits a set of meanings and also their permanent change.

In today's global reality of education children education is based on the ideas of free education paradigm and these ideas refer to philosophy of postmodernism. Postmodernism is associated with literature, language games and is identified as a new thinking and acting style, manner which is as if not based on anything, is free and at the same time is new, original. Postmodernism rejects conventional definitions, perspectives and limits. Boundaries between oppositions also shrink: real and fake, strong and fragile. Actions become more important than the result, the uncertainty than definition, the intermission than linearity, the difference than similarity, the copy than original, and the deconstruction than reconstruction. The permanent presence in a situation of uncertainty is associated with the immediate experience (Duoblienè, 2006).

In the process of education not only pedagogical principles and technical and practical application of training methods are important, but also their philosophical justification and interaction. Changes in society have an impact on transformation of educational paradigm; therefore, relevant social phenomena must be felt in the process of education in this way seeking for interaction of society and education (Garšvè, 2014).

Following postmodern ideas, we confront a completely new approach to the process of education, its theory and theory proportion to practice. In the process of education it is not necessary to have a clear situation, plan and results (Fullan, 1998). Already in the action of process one can move in uncertainty by adjusting the plan and the result is not the most important element of this process. In the 
context of postmodernism human sense of self-creation reveals itself (Rubavičius, 2003). In A. Juodaityte's (2003) opinion there is an opportunity to review complex links of child - adult - education system.

Child education in his childhood is designed on the basis of child's socialcognitive experience and it becomes a constantly evolving context of social interaction with environment. Such education is important not only for a child, but also for an adult because it is seen as a dialogue of two cultures. This dialogue means that a child and an adult mutually start creating a social project "here and now". The project is addressed to children and aims to solve most important social tasks in micro environment. By mutually learning solidarization and solving human problems, it is taught to solve them on the basis of interaction of people groups, a child and an adult who have different experience. Intercultural dialogue of a child and an adult provides their relationship with meaning (Juodaityte, 2003).

V. Glebuvienè, B. Grigaitè and O. Monkevičienè (2002) emphasize that a dialogue interaction of a child and an adult must not as much guarantee the cognitive child development, but has to help unfold his self-awareness and selfesteem. This dialogue must also help promote harmonious relations with the environment, people and a child himself. According to authors, the basis of such interaction is fast adult's reaction to child's needs, desires and requests, constant adult attention to child's activities, creation of opportunities for the child to communicate, development of emotional contact, child's recognition by little emphasizing or even not emphasizing his misbehaviour.

As for the mutual dialogue of a child and an adult and the expression of a dialogue A. Juodaityte (2007) emphasizes that children's participation in social life opportunities are often perceived by the same criteria which are applied to adults. Children are classified as having socially insignificant roles and adults become supervisors and people of control. Children try to escape from their care in reasonable ways by contradicting to adult's opinion, ignoring it, behaving in a way which would be surprising and interesting to adults. In such ways children seek to become adults or behave similar to them. For this reason children choose a different path and in respect of adults they behave in a conformist way, early lose the ability to express their opinion, refuse to consider and decide individually and in any way seek for a positive adult approach to them.

According to L. Duoblienè (2006), modern education of children is based on the principle of dialogue by highlighting your reconsideration of position, assumption and power games. A dialogue is based on the project of questions and answers when it is important to recognise differences and treat another as a partner by seeking for an equal intercultural dialogue in the process of education.

When faced with different intercultural experiences in the process of education, most often it is confronted with uncertainty and failure to accept 
another person. For this reason the conditions of an intercultural dialogue are not constituted. R. Godon (2004) emphasizes that hermeneutics in education comprises of three main elements which are among the most important factors in the process of education for children reflecting different experiences: understanding, personal identity and education. It creates possibilities to understand and analyse "different" children educational problems caused by the absence of a dialogue between a teacher and a learner. It follows that hermeneutics in the process of education must perform a function of meaning disclosure which would help to understand the diversity of children not as a negative aspect but as an organizational aspect of educational process, as an equal partner's aspect of a child and an adult. Hermeneutics in the process of education allows revealing a process of change in understanding between learners and a teacher (Garšvé, 2011; Lukočiūtė et al., 2009).

A child and an adult have to learn from each other and a constant dialogue has to remain in their relationship. M. Buber (1984) confirms this in his works by analysing „I-you“ and „I-this" relationship. When relationship of „I-this“ occurs a child to a teacher is someone who needs to be directed and given knowledge. A child is an object who is manipulated by a teacher. Relationship of „I-you“creates preconditions for a teacher and a child to learn from each other. In developing such relationship, knowledge, feelings and aspirations are shared. Everyone involved in this relationship is a teacher as well as a learner communicating with the other as a person. According to the author, even though a teacher and a learner differ in knowledge, they are equal in a dialogue.

Intercultural dialogue and its expression in pre-school enable a different understanding of the relationship between a teacher and a learner: i. e. from a teacher as a subject and from a learner as an object. To understand this relationship two models are chosen: the theory of Banks's Typology of Ethnicity and Milton Bennet's model of intercultural sensitivity which are both focused on the process of education. This process oriented model specifies how participants of educational process change by realising cultural identity of another and refers how favourable conditions are developed through dialogue with another person. Also, this process-oriented model helps to construct behaviour of a teacher, his habits and relationship with a learner (Freire, 2009). As J. Banks (1994) states, a variety of experiences is raised, i. e. interactive methods of education are used: simulation, communication with people of different cultural backgrounds to allow the reflection of experiences.

L. Garšve (2011) emphasizes that an important aspect for the development of intercultural understanding becomes a transition to phases of multiidentity and reflection. In this stage, a shift occurs from cultural aspects to deep ones, i. e. perception, value assessment, symbols. In this stage, a teacher and a learner create a reflective environment in which each of them accept each other's experience by 
sharing it and then they return to their experiences and reflect on it from the beginning. Openness for different cultures is being formed and the relationship between „I and the other" is given meaning. When in globalizing world changes relate to mixing of cultures, fundamental provisions of intercultural understanding become the search for cultural dialogue. This challenges new starting points and can promote an intercultural dialogue, search for new meanings, and selfreflection as education of self-cultivation in formal educational environment (Schachinger, 2000, p. 14).

L. Garšve (2014) believes that the process of education in formal environment is not a static but a dynamic process which can be enriched with hermeneutics. According to the author, often the process of education is full of illusions because prejudices and stereotypes are not reflected. Hermeneutics focuses on the analysis of prejudices, habits and illusions not by rejecting them but trying to critically understand them. Hermeneutics also emphasizes the search for meanings and decodation of educational process participants who reflect different experiences. The importance of a child in formal educational process is emphasized by constantly paying attention to his experience at the same time encouraging him to get involved in the processes of experience development (Juodaityte, 2003).

According to L. Garšve (2014), hermeneutics is a method of understanding and interpreting experience. Interpretation of meanings is performed quite playfully and vaguely. The game field of hermeneutics is very wide and opens further horizons. The game is based on education as synthesis of horizons principle when faced with traditions is important to hear the voice of another person. The collision is perceived as a clash between the one who knows and the learner, between the learner and his object of learning. In this synthesis of horizons, understanding and language are important (Fairfield, 2011).

The role of hermeneutics teacher in formal education consists of three main domains: a) the change of teacher's position in educational process, b) critical interactive relationship with socio-cultural, political, economic and technologic environments, c) teacher's permanent need to learn and improve. Firstly, hermeneutics teacher changes from traditional teacher, i. e. teacher as an organizer of educational process, to learner assistant seeking for self-understanding in the process of education. A teacher is an assistant who creates connection between learner's understandings of experiences. This relationship turns to openness of risk, misunderstandings, and contingencies on the basis of which dialectical connection between notoriety and otherness is built. Secondly, the role of hermeneutics teacher provides with the usage of new information technologies in the process of education, with critical creative relationship with disinformation, addictions, and social degeneration (such as personal isolation). An important role of a teacher as an interpreter of cultures. Thirdly, the role of hermeneutics teacher 
in the context of existential philosophy must be based on creative self-education focusing on literature, body movement, artistic expression, improvisation and interpretation by developing cognitive skills as presumption to openness of otherness (Garšvè, 2014; Duoblienè, 2006a; Fullan, 1998).

Hermeneutical method allows explaining the multiplicity of human's being in the world and the multiplicity of education and it opens a way to a dialogue between "I" and "You", i. e. between a child and an adult. A dialogue offers opportunities to gradually overcome miscommunication (Juodaityte \& Savickis, 2013). In the process of education hermeneutics is based on the interpretation and adaptation of experience and practical application for a particular text. With the help of reflection a teacher is able to move the understanding of object and broaden the previous understanding which is constantly being improved with the help of reflection (Mažeikis \& Lenkauskaitè, 2008).

According to L. Duoblienè (2006), hermeneutics in the process of education actualize the educational principle of skills interpretation. The act of interpreting does not rely on authorities and is a process performed freely in the format of the game which maintains a dialogue to achieve a different perception of reality. There is no final word in such environment. A dialogue and its expression help avoiding a forced consensus and increases involvement (Mažeikis \& Lenkauskaitè, 2008).

Thus, in post-modern society childhood period is important in cultural, social and spiritual senses and that is why it takes on a significant meaning when dealt with children education. Modern education of children in pre-school is based on an intercultural dialogue, its expression which is complemented and enriched with hermeneutics. Hermeneutics in the context of global processes creates conditions to view children education as multi-dimensional, unique in respect of different cultures' process in formal educational environment.

\section{Conclusions}

A dialogue is created and developed through communication processes by seeking to change and discover new meanings and interpret experiences. A dialogue focuses on the problem of understanding where not as much participation and interaction are particularly important but the understanding of whole.

A dialogue as one of the most important communication forms of a child and an adult occurs in various educational environments: formal and informal by maintaining an open dialogue between two personalities with different cultural level, i. e. child's and adult's, in which the most important moment is constant attention to child's experience.

Modern education of children in pre-school is based on an intercultural dialogue, its expression which is enriched with hermeneutics. The method of 
hermeneutics in formal educational environment allows revealing the change of understanding between a learner and a teacher who reflect different experiences. By applying this method a dialogue relies on the project of questions and answers when it is important to recognise differences and treat another person as an equal partner. Thus, intercultural dialogue and its expression of a child and an adult in pre-school allow revealing and understanding the diversity of experiences of a child and an adult, a learner and a teacher.

\section{References}

Banks, J. (1994). Multiethnic Education: Theory and practice. Needham Heights, MA: Allynand Bacon.

Bitinas, B. (2004). Hodegetika. Auklëjimo teorija ir technologija. Vilnius: Kronta.

Buber, M. (1984). Das dialogische Prinzip. Heidelberg.

Corker, M., \& Shakespeare, T. (Eds.) (2002). Disability/postmodernity. Embodying Disability Theory. London-NewYork. Continuum.

Čičelis, R. (2013). Dialogas ir hermeneutikos tradicija. Colloquia, 32, 180-185.

Duoblienè, L. (2006). Šiuolaikine ugdymo filosofija: refleksijos ir dialogo link. Vilnius: Tyto alba.

Duoblienè, L. (2006a). Tarpkultūrinis ugdymas: tautinio tapatumo ir/ar dialogo su Kitu paieškos. Lietuva globalejančiame pasaulyje. Vilnius: Logos.

Fairfield, P. (2011). Dialogue in the Classroom. Education, Dialogue and Hermeneutics. Continuum International Publishing Group: New York, 77-90.

Freire, P. (2009). From Pedagogy of the Oppressed. Race/Ethnicity: Multidisciplinary Global Perspectives. Vol. 2, No. 2, 163-174.

Fullan, M. (1998). Pokyčiu jegos. Vilnius: Tyto alba.

Garšvè, L. (2014). Hermeneutinè pedagogika kaip edukologijos metodologija. Šiuolaikinès hermeneutikos iššükiai ir problemos, 17, 175-188.

Garšvè, L. (2012). Tautinio tapatumo slinktys postmodernioje visuomenëje. Jaunuju mokslininku darbai, 5 (38), 64-68.

Garšvè, L. (2011). Lietuvių kilmės mokiniu identitetų ugdymas: naujojo diskurso konstravimas remiantis postmodernosiomis filosofijos teorijomis. Mokytoju ugdymas, 17 (2), 25-37.

Gellner, E. (1993). Postmodernizmas, protas ir religija. Vilnius: Pradai.

Gillert, A. (2003). Intercultural Learning T-kit. Nr. 4. Downloaded from: http://pjp-eu. coe.int/documents/1017981/1667917/tkit4.pdf/1e4f2f12-6448-4950-b0fd5f4c94da38 e2

Glebuvienè, V., Grigaitè, B., \& Monkevičienè, O. (Eds.) (2002). Lietuvos vaiku brandumas mokyklai: tyrimas ir problemos. Vilnius: Švietimo aprūpinimo centras.

Godon, R. (2004). Uderstanding, Personal Identity and Education. Journal of hilosophy of Education. Vol. 38, No. 4, 589-600.

Gutauskas, M. (2010). Dialogo erdvè. Fenomenologinis požiūris. Vilnius: Vilniaus universiteto leidykla.

Yoshida, T., \& Matsumoto, D. (2002). The Japanese Returnee experience: factors that affect reentry. International Journal of Intercultural Relations. Vol. 26, No. 4, 429-445.

Jakavičius, V. (1998). Žmogaus ugdymas. Kaunas: Šviesa.

Jovaiša, L. (2003). Hodegetika. Vilnius: Agora. 
Juodaitytè, A., \& Savickis, A. (2013). Hermeneutikos metodo taikymas šiuolaikiniame edukologijos moksle. Acta Pedagogica Vilnensia, 30, 24-33.

Juodaitytè, A. (2007). Vaikystė kaip socialinè negalè: mitologizuoto diskurso konstravimas ir sklaida socialinèje, pedagoginèje realybèje. Socialinis darbas, 6 (1), 104-112.

Juodaitytė, A. (2004). Vaikystès pedagogo pasaulěžiūrinè koncepcija: „laisvojo“ ugdymo kontekstas. Pedagogika, 70, 87-91.

Juodaitytė, A. (2003). Vaikystès fenomenas: socialinis-edukacinis aspektas. Šiauliai: Šiaulių universiteto leidykla.

Juodaityte, A. (2002). Socializacija ir ugdymas vaikystejje. Vilnius: Petro ofsetas.

Kazlauskienè, A. (2012). Dialogo kultūra grịstas mokslo ir studiju kokybès valdymas Šiauliu universitete. Downloaded from: http://www.su.lt/bylos/RsV/Laikrastis/siauliu\%20 universitetas\%20nr.9\%202012. pdf

Kontautienė, R. (2006). Bendradarbiavimo sistema ir jos valdymas mokykloje. Klaipėda: Klaipèdos universiteto leidykla.

Lukočiūtè, L., Mažeikis, G., \& Mickutė, R. (2009). Hermeneutinė klasė: iš užsienio grị̌usių mokinių tapatybès švytuoklè ir jos supratimas. Jaunuju mokslininku darbai, 4 (25), 4449.

Martišauskienė, E. (2008). Ugdomojo mokymo retrospektyva ir dabartis (V. Rajecko „Ugdomojo mokymo“ ir konstruktyvizmo paralelès). Pedagogika, 89, 11-17.

Mažeikis, G., \& Lenkauskaitè, J. (2008). Dėstytojų gebėjimai adaptuoti kooperuotų studijų metodą: Šiaulių universiteto, Šiaulių bei Panevěžio kolegijų patirtis. Jaunuju mokslininku darbai, 1 (17), 82-88.

McLaughlin, T. (1997). Šiuolaikinè ugdymo filosofija: demokratiškumas, vertybès, ìvairovè. Kaunas: Technologija.

Mickūnas, A. (2014). Mokykla, mokytojai, mokiniai. Vilnius: Versus Aureus.

Monkevičienè, O. (2009). Lietuvos švietimo reforma: ikimokyklinio ugdymo turinio ir pedagoginių technologijų kaita 1988-2008. Mokytoju ugdymas, 12 (1), 104-120.

Rau, J. (2005). Kultūrų dialogas - dialogo kultūra. Tolerancija vietoj nureikšminimo. Vilnius: Dialogo kultūros institutas.

Rubavičius, V. (2003). Postmodernusis diskursas: filosofine hermeneutika, dekonstrukcija, menas. Vilnius: Kultūros, filosofijos ir meno institutas.

Schachinger, W. (2000). Limiting distributions for the costs of partial match retrievals in multidimensional tries. Random Structures \& Algorithms, 17, 428-459.

Schröer, N. (2009). Hermeneutic Sociology of Knowledge for Intercultural Understanding. Forum Qualitative Sozial forschung/Forum:Qualitative Social Research. Vol. 10, No. 1.

Sotirou, P. E. (2012). The Pedagogical Implications of Hans-Georg Gadamer's Hermeneutics: Alternatives for Teaching Students How to Readand Write. United States: EdwinMellen Press.

Sotirou, P. (1993). Articulatinga Hermeneutic Pedagogy: The Philosophyof Interpretation. Journalof Advanced Composition.

Sterfeld, E., \& Mathiasen, C. R. (1999). Pedagogika ir demokratija/Ugdomojo darbo eksperimentai Lietuvos vaiku darželiuose. Vilnius: Aidai.

Tanaka, M. (2005). The Cross-Cultural Transfer of Educational Concepts and Practices: A Comparative Study. Oxford: Symposium Books.

Wojtyla, K. (1997). Asmuo ir veiksmas. Vilnius: Aidai. 


\section{MŪŽIZGLİTīBA LIFELONG LEARNING}


